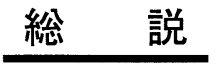

\title{
日本における廃食用油の発生・回収・再生の 現状と問題点
}

\author{
薄 木 理一郎 \\ 尚絧女学院短期大学生活科学科 (テ981-12 宮城県名取市ゆりが丘 4-10-1)
}

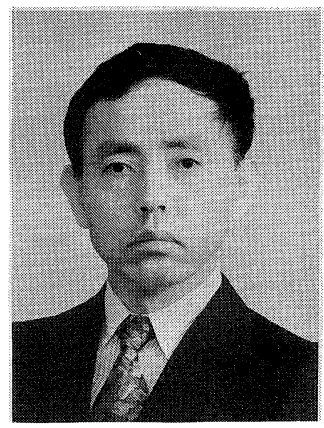

Some Aspects of Generation, Collection and Regeneration for Recycling of Used Frying Oil in Japan

\author{
Riichiro UsUKI \\ Department of Living Science, Shokei Women's Junior College \\ (4-10-1, Yurigaoka, Natori-shi, $\mathbf{T} 981-12$ )
}

\begin{abstract}
Govermental agency have published through analytical researches that the total amount of consumption of edible fats and oils in Japan is about 2,000,000 t every year, in which 400,000 t is discharged as the used frying oil. The part of waste oil $(180,000 \sim 200,000 t)$ is collected from food service business and food industry and regenerated for reuse.

My investigation indicated that most of used frying oil from household finally have been burnt up as garbages after some treatment. For the purpose of the establishment of new recycling system for the collection, regeneration and reuse of used frying oil (about 150,000 t from household), an adequate volume of used oil with good quality should be secured, other use of collected waste oil should be discovered and the industrial power of oil collection trader and oil regeneration trader shoud be built up.
\end{abstract}

\section{1 はじめに}

近年，地球環境保全や天然資源の有効利用などに対す る関心が急速に高まり，企業の社会的責任はもとより， 日常の家庭生活の点検・見直しも論議されている。1991 年 10 月に「再生資源の利用の促進に関する法律」(いわ ゆる「リサイクル法」) が施行され，廃棄物処理の問題 は新たな段階に入ったが, 最近の景気低迷の中でさまざ まな問題を生じて，社会的な問題となっている。

わが国で年間約 40 万 $\mathrm{t}$ 発生している廃食用油はリサ イクル法の対象とはなっていない。これまで一部が業者 によって回収され, 飼料, 脂肪酸工業などに再利用され ていることは知られていたが, どれだけの量の食用油が どのように処置されているか，その実態は不明であっ た。

農林水産省食品流通局は 1988 年「食用油流通・回収 システム等ガイドライン作成事業」を開始したが，その 社会的背景として, 急激な円高が進行する中で油糧種子 の国際的な需給緩和が続き，とくにマレーシア等からの パーム油の輸入増大が, 国内の廃油回収・再生業者の経
営を圧迫し, 回収されずに廃棄される量が増えることが 懸念された状況があった。さらに河川や湖沼をめぐる環 境污染への関心の高まりとともに，それまで顧みられな かった家庭から排出される食用油の回収・再生の可能性 について検討する必要性が生じていた。

上記事業の初年度は, 家庭及び食品産業における廃食 用油の処理の実態，回収・再生業の実態などが調査され た1)。本稿では，これらの調査の内容を紹介するととも に, 著者が行った家庭から出る廃食用油の処置に関する 調查結果も ${ }^{2)}$ 交えて, わが国における廃食用油の処置の 現状と問題点について考えてみたい。

\section{2 廃食用油の発生状況}

\section{$2 \cdot 1$ 廃食用油の発生量}

廃油量を算出するにあたっては, 廃棄率が検討され, Table-1 に揭げる数值が使われた。これらの数値の 中, 家庭の廃油量は, 昭和 61 年 9 月 28 日から 10 月 25 日まで行われた東京都目黒区の家庭ごみ計量調査に基づ いており，また業務用については，昭和 63 年 12 月に実 施されたアンケート調査 ${ }^{1}$ に基づいて, 1 社 (1 店) 当た 
Table-1 Estimation of percentage of waste frying oil in the consumption of edible fats and oils.

\begin{tabular}{|c|c|c|c|c|c|c|c|c|}
\hline & & \multirow{3}{*}{$\begin{array}{l}\text { Household } \\
\text { kg/person/ } \\
\text { year }\end{array}$} & \multicolumn{2}{|c|}{$\begin{array}{l}\text { Food manufacturer } \\
\text { t/Co./month }\end{array}$} & \multicolumn{4}{|c|}{$\begin{array}{l}\text { Food service industry } \\
\mathrm{kg} / \text { store/month }\end{array}$} \\
\hline & & & \multirow{2}{*}{ Noodle } & \multirow{2}{*}{$\begin{array}{l}\text { Fish paste } \\
\text { products }\end{array}$} & \multicolumn{2}{|c|}{$\begin{array}{l}\text { Feeding service } \\
\text { business }\end{array}$} & \multirow{2}{*}{$\begin{array}{c}\text { Mass } \\
\text { feeding } \\
\text { service }\end{array}$} & \multirow{2}{*}{$\begin{array}{c}\text { Daily } \\
\text { dish } \\
\text { service }\end{array}$} \\
\hline & & & & & Vegetable & Animal & & \\
\hline Amount of consum & tion & 4.40 & 166.4 & 6.42 & 599 & 604 & 589 & 554 \\
\hline Amount of waste o & & 0.7 & 2.94 & 0.87 & 257 & 261 & 203 & 231 \\
\hline Percentage of wast & oil & 15.9 & 4.6 & 19.6 & 53.3 & 48.0 & 39.0 & 49.0 \\
\hline \multicolumn{9}{|c|}{$\begin{array}{l}\text { Amount of waste oil does not mean the total amount of used frying oil, which contain the loss volume } \\
\text { during operation. It means the amount to be collected for reuse in any way. }\end{array}$} \\
\hline \multicolumn{9}{|c|}{ Table-2 } \\
\hline \multirow{2}{*}{\multicolumn{2}{|c|}{ Use }} & \multirow{2}{*}{\multicolumn{2}{|c|}{ User }} & \multicolumn{3}{|c|}{ g/person/year } & \multirow{2}{*}{\multicolumn{2}{|c|}{$\begin{array}{c}\text { Total amount of } \\
\text { waste oil } \\
\text { (1000 t/year) }\end{array}$}} \\
\hline & & & & Oil supply & Loss & Waste oil & & \\
\hline \multirow[t]{2}{*}{ Frying oil, etc., } & \multicolumn{2}{|c|}{ Household } & & 4,394 & 879 & $950 \sim 1,758$ & \multicolumn{2}{|c|}{$117 \sim 216$} \\
\hline & \multicolumn{3}{|c|}{ Food service business } & 4,760 & 952 & 1,428 & \multicolumn{2}{|c|}{175} \\
\hline Margarine, etc., & \multicolumn{3}{|c|}{ Oil processing factory } & 3,127 & 625 & 156 & \multicolumn{2}{|c|}{19} \\
\hline Other processing & \multicolumn{3}{|c|}{ Food industry } & 4,374 & 875 & 437 & \multicolumn{2}{|c|}{54} \\
\hline \multicolumn{4}{|c|}{ Total } & 16,655 & 3,331 & 2,971 & \multicolumn{2}{|c|}{$365 \sim 464$} \\
\hline
\end{tabular}

Table-3 Amount of waste frying oil from household in several reports.

\begin{tabular}{lcc}
\hline \multicolumn{1}{c}{ Research } & g/person/year & Date of research \\
\hline 1. Monitering research for food consumption & $(\mathrm{A})^{*} 938 ;(\mathrm{B})^{* *} 516$ & 1988 \\
2. Meguro Ward, Tokyo & 694 & Oct., 1986 \\
3. Shibuya Ward, Tokyo & 1,440 & Oct., 1984 \\
4. Edogawa Ward, Tokyo & $454 \sim 751$, mean 649 (Collected volume) & 1988 \\
5. Kyoto City & 360 & Mar., 1982 \\
6. Fujieda City, Shizuoka & 260 (Collected volume) & 1987 \\
7. Kaga City, Ishikawa & 422 (Collected volume) & 1982 \\
8. Yaizu City, Shizuoka & 54 (Collected volume) & 1988 \\
9. Sendai City and environes & 1,100 & June, 1991 \\
\hline
\end{tabular}

* This average value was evaluated in the houshold from which waste frying oil was generated.

** This average value was evaluated in the total household.

りの使用量は廃油量と対応する回答企業のみについて算 出し, 廃油率は 1 社 (1 店) ごとの廃油率の平均として 示されている。外食産業の廃油率が, 比較的廃油が多い といわれている水産練り製品業の 2〜2. 7 倍と高いこと が注目される。

食品工業の廃油率は業種全体からみるとかなり低いと 考えられるので $10 \%$ と見込み, 外食産業の廃油率は, ファーストフードなどの食用油はかなり効率的に利用さ れていることを考慮して $30 \%$ と推定して, わが国での 廃棄量の全体像を推定すると, Table-2 のようになっ た。食品製造業と外食産業の廃油率の平均 $33 \%$ を用い て求めた業務用からの廃油量は 30.5 万 $\mathrm{t}$ となり, 従来
業界で議論されてきた 20〜30万 $\mathrm{t}$ の数值と一致した。 その後の調査委員会の検討では, 市場に流通している廃 食用油は発生ベースで約 $25 \sim 28$ 万 t, その内回収・再利 用されている量が約 18～20万 t と推定している3)。

家庭からの廃油も含めた発生廃油量の合計は，家庭に おける廃油率に幅があることから 36〜 46 万 t と計算さ れ，総消費量の約 $1 / 4$ に達することになる。この約 40 万 $\mathrm{t}$ の内約半分程度しか再利用されておらず, 残りは廃 棄または回収後の損失となっているものと思われる。

個々の家庭からの廃油発生量については, Table-3 に揭げるような各自治体の調査がある。調査によって大 きな差がみられ，実際に回収した量を示している藤枝市 
などの場合は小さい値を示している。妥当性のある調査 としては, 食料品消費者モ二夕一調查, 目黒区及び江戸 川区調査と推定され，ここでも年間一人当たりの発生量 は 450 1440 g とかなりの幅があるが，平均 $950 \mathrm{~g}$ とみ なしている4)。上記調査の中には, 調查年月日の古いも のも見受けられるが，近年家庭における食用油の使用方

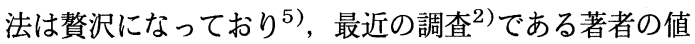
: $1100 \mathrm{~g}^{2)}$ も妥当な数值と考えられる。

\section{$2 \cdot 2$ 食品工業における廃食用油の処置}

日本即席食品工業協会, 全国蒲鈝水産加工業協同組合 連合会, 日本ポテトチップス協会, 全国油菓工業協同組 合を通じて行った 106 社からの回答は次のような事実を 示している1)。

$53.8 \%$ の企業に廃油の発生があり, 業種別では, 水 産練製品製造業からの発生が $84.8 \%$ 之高く, 麵類製造 業 (43.3\%) がこれに続いているが，それ以外の業種で の廃油発生は少なかった。

廃油の処理方法について, 廃油が発生すると回答した 57 社に自社で処理している 4 社を加えて分析した結果
をTable-4に示した。 84 \%を超える多くの企業は回 収業者または廃油再生業者による処理を行っていたほ か, 産業廃棄物処理業者に出しているのが 4 社あった。

廃油の売買状況は,「回収業者などが廃油を買う」が $43.1 \%$,「無料」が $39.2 \%$,「回収料を支払う」が 23.5 \%となっていた。業種別では，即席中華麵を製造して いる麵類製造業が「廃油を買う」53.8％が最も多く, 水産練製品製造業は「無料」 $48.6 \%$ が多くなってお り，業種によって廃油の品質が異なるためであろう。

これらの調查には豆腐製造業が含まれていないなど, 食品工業全般をカバーしているとは言いがたいが，初め て行われた調查として意義あるものと言えよう。

\section{$2 \cdot 3$ 外食産業における廃食用油の処置}

日本フードサービス協会，日本給食サービス協会，日 本惣菜協会を通じて行った 163 社に対する調查の結果は 次のようであった。

$91.9 \%$ の企業から廃油の発生があり，業種別では, 集団給食企業が $100 \%$ である一方, 鴾菜製造業での発 生は $78.3 \%$ と少ない。

Table-4 Treatment of waste frying oil in food manufacturers.

\begin{tabular}{|c|c|c|c|c|c|c|}
\hline & Total & $\begin{array}{l}\text { Oil collec- } \\
\text { tion trader }\end{array}$ & $\begin{array}{l}\text { Oil regenera- } \\
\text { tion trader }\end{array}$ & $\begin{array}{l}\text { Disposal trader of } \\
\text { industrial waste }\end{array}$ & As fuel oil & $\begin{array}{l}\text { Incineration } \\
\text { in factory }\end{array}$ \\
\hline $\begin{array}{l}\text { Biscuits and dry } \\
\text { confectionaries }\end{array}$ & 2 & - & 1 & 1 & 1 & 1 \\
\hline Rice cake & 1 & 1 & - & - & - & - \\
\hline $\begin{array}{l}\text { Other confectio- } \\
\text { naries \& bread }\end{array}$ & 1 & - & 1 & - & - & - \\
\hline Noodles & 14 & 9 & 4 & 1 & - & - \\
\hline $\begin{array}{l}\text { Fish paste } \\
\text { products }\end{array}$ & 39 & 30 & 5 & 2 & 3 & - \\
\hline Others & - & - & - & - & - & - \\
\hline Total company & $\begin{array}{c}61 \\
(100 \%)\end{array}$ & $\begin{array}{c}40 \\
(65.5 \%)\end{array}$ & $\begin{array}{c}11 \\
(18.0 \%)\end{array}$ & $\begin{array}{c}4 \\
(6.6 \%)\end{array}$ & $\begin{array}{c}4 \\
(6.6 \%)\end{array}$ & $\begin{array}{c}3 \\
(4.9 \%)\end{array}$ \\
\hline
\end{tabular}

Table-5 Treatment of waste frying oil in several food service industry.

\begin{tabular}{|c|c|c|c|c|c|c|c|c|c|}
\hline & Total & $\begin{array}{l}\text { Oil } \\
\text { collection } \\
\text { trader }\end{array}$ & $\begin{array}{l}\text { Use of } \\
\text { gel-form- } \\
\text { ing agent }\end{array}$ & $\begin{array}{l}\text { Absorp- } \\
\text { tion in } \\
\text { paper }\end{array}$ & $\begin{array}{l}\text { Flushing } \\
\text { down } \\
\text { the drain }\end{array}$ & $\begin{array}{l}\text { Industrial } \\
\text { waste } \\
\text { trader }\end{array}$ & $\begin{array}{l}\text { Burying } \\
\text { in the } \\
\text { ground }\end{array}$ & $\begin{array}{l}\text { Source in } \\
\text { soap and } \\
\text { other } \\
\text { products }\end{array}$ & $\begin{array}{l}\text { Incinera- } \\
\text { tion in } \\
\text { factory }\end{array}$ \\
\hline Feeding service & & & & & & & & & \\
\hline business & 83 & 80 & 4 & 1 & - & 2 & - & - & - \\
\hline $\begin{array}{l}\text { Mass feeding } \\
\text { service }\end{array}$ & 47 & 43 & 3 & 2 & - & 2 & 1 & 1 & - \\
\hline $\begin{array}{l}\text { Daily dish } \\
\text { service }\end{array}$ & 19 & 19 & - & - & - & - & - & - & 1 \\
\hline Total company & $\begin{array}{c}149 \\
(100 \%)\end{array}$ & $\begin{array}{c}141 \\
(94.6 \%)\end{array}$ & $\begin{array}{c}7 \\
(4.7 \%)\end{array}$ & $\begin{array}{c}3 \\
(2.0 \%)\end{array}$ & - & $\begin{array}{c}4 \\
(2.7 \%)\end{array}$ & $\begin{array}{c}1 \\
(0.7 \%)\end{array}$ & $\begin{array}{c}1 \\
(0.7 \%)\end{array}$ & $\begin{array}{c}1 \\
(0.7 \%)\end{array}$ \\
\hline
\end{tabular}


「社内で焼却する」として「廃油なし」と回答してい た 1 社を加えた 149 社の廃油処理法は Table-5 のよう であった。95\%に近い企業が「回収業者による処分」 を実施しており，廃油の売買状沉は，「回収料を支払 う」57.6\%が最も多く,「無料」 $30.9 \%$,「回収業者が 廃油を買う」 $10.8 \%$ であり, 業種による差異は見られ なかった。

\section{$2 \cdot 4$ 家庭における廃食用油の処置}

家庭における食用油の使用状況之廃棄方法に関しての 調查は Table-3 に掲げる自治体を中心とするものがあ るが, 調查方法が異なるため, その結果の解釈も微妙に 違っている。

著者は，東北地方における調査が全くみられなかった ので, 主として仙台市及びその近郊に居住する本学生 活科学科学生及び教職員の家庭について調査を実施し $た^{2)}$ 。調查は 1991 年 6 月, 回収された 477 世帯につい て集計した。

家庭で行っている廃棄方法とその是非について尋ねた (Table-6) ところ,「紙や布に吸わせて棄てる」が 35.5 \%で最も多く, 次いで「市販の凝固剂・吸収パックで 処理する」が合わせて $41.1 \%$ を数え，「自宅で燃や す」を含めると, 約 8 割の廃食用油が最終的にごみとし て焼却されていることが明らかとなった。使いきって廃 油を出さない家庭は $3.8 \%$ と, 他都市の調査, 17 45 $\%^{6)}$ に比べて非常に小さい数值を示し, 食用油をかな り贅沢に使用していることを伺わせた。

前述の調查 ${ }^{6)}$ と比較すると, 「流しに棄てる」割合が 激減し,「市販廃油処理剂を使用する」が著しく増加し ている。およそ 5 年の時間経過が主婦の意識を変えてい る結果を推測される。

「その他」の中には，「牛乳パックに入れて棄てる」 「せっけんにして再利用する」などがあったが, ごく一 部に限られた。
自分の行っている処置法の是非について尋ねたところ (Table-6),「流しに菓てる」はよくないと思っている ことは予想どおりであったが，「土に埋める」「自宅で燃 やす」に対する評価が高かったのが注目される。また凝 固剂や吸収パックによる処理は約 7 割の家庭が「よい方 法である」と考えており，その効果に満足している消費 者が多かった。

以上の調查から, 家族数 4.67 人の家庭における食用 油の平均的な使用状況を推察すると,「年平均 $13.6 \mathrm{~L}$ の油を使用して, 週平均 2.3 回のフライ調理を行い, 平 均 3.2 回使用した後, 年平均 $5.74 \mathrm{~L}$ の廃油を発生して いる。廃食用油の大部分は市販の廃油処理剂で処理さ れ，ごみとして焼却されている」ことになる。

このような事実から, Table-2 に示される約 15 万 t 前後の家庭廃食用油の大部分が再利用されずに廃棄され ていると見なされる。

\section{3 廃食用油の回収・再生の実態}

\section{$3 \cdot 1$ 廃油回収業における回収・再生}

回答を寄せた 44 社の内 36 社が個人経営であり, 32 社の従業員数が 5 名未満と, 廃食用油の回収の大部分が 零細な個人企業によって行われている。「廃油回収だけ を行っている」のは $52.3 \%$ であり, 残りは「廃油回収 業と回収廃油の一部再生」または「廃油回収業之回収廃 油のほとんどを再生」していた。このように廃食用油を 回収する業者には, 回収だけを行う業者と再生まで行う 業者とがある。

回収する内容物が「廃油だけ」はわずか $9 \%$ に過ぎ ず，残りは揚げかす(粕)を一緒に回収している。

回収先の業種別に取引状況を見てみると，一般住宅で は「回収料を取っている」 15 社 $(65.2 \%)$,「無料」 10 社 $(43.5 \%)$ と二分しており, レストランなどの営業給 食は「回収料を取っている」が $75 \%$ 程度で,「無料」

Table-6 Disposal treatment of waste frying oil and self-judgement for its pertinency in household.

\begin{tabular}{lcccc}
\hline \multirow{2}{*}{ Disposal treatment } & & \multicolumn{3}{c}{ Self-judgement } \\
\cline { 3 - 5 } & & Good & Unavoidable & Bad \\
\hline Flushing down the drain & $3.8 \%$ & $16.7 \%$ & $29.2 \%$ & $45.9 \%$ \\
Buring into the ground & 8.0 & 42.8 & 36.0 & 14.6 \\
Incineration by oneself & 4.6 & 45.7 & 40.0 & 10.0 \\
Absorption in clothes and paper & 35.5 & 42.6 & 39.6 & 5.0 \\
Commercial gel-forming agent & 29.7 & 56.9 & 33.5 & 1.3 \\
Commercial adsorbent & 10.4 & 65.4 & 28.4 & 0 \\
Commercial oil emulsifier & 1.1 & 25.0 & 50.0 & 0 \\
Absence of waste oil & 3.8 & 70.0 & 5.0 & 5.0 \\
Other & 2.0 & 10.9 & 10.7 & 53.6 \\
\hline
\end{tabular}


が $50 \%$ 程度である。集団給食では「無料」56.1\%が 多く,「回収料を取っている」と「購入している」と 40 $\%$ 程度で二分している。惣菜業は「回収料を取ってい る」 $67.6 \%$,「無料」 $51.4 \%$ で，食品製造業は「回収 料を取っている」 58.8 \% ,「無料」 $41.2 \%$ となってい る。この他「新しい油や洗剂を売る」が全業種にわたっ て 9 19\%見られた。以上の結果は, 営業給食で回収 料を取っている割合が高くなっているものの，全体とし ては「購入している」割合は少なく, 廃油の品質とそれ までの回収先との取引状況次第で違ってくることを示し ている。

回収した廃油を「そのまま販売している」のが 21 社 (51.2 \%), で「再生して販売している」のが 24 社 (58.2 \%)で，販売先としては，レンダリングまたは再生企業 が 39 社と最も多く, 飼料製造企業 12 社, 脂肪酸企業之 その他が 5 社となっていた (Table-7)。

廃油回収業者にとっての問題は,「回収先の廃油の減 少」「同業者の競争激化」「回収先との価格交涉」が上位 を占め,「回収先廃油の品質低下」「後継者の不足」がこ れに次いでいた。

国や地方公共団体への要望事項としては，「パーム油 輸入の自肃」「同業組合の育成」「再生新技術の開発」が 上位を占めていた。

なお, 廃食用油の回収には一部産業廃棄物処理業者が 行っているものもあり，その大部分は廃棄処分されてい るものと思われる。

\section{$3 \cdot 2$ レンダリング・廃油再生業における実態}

日本レンダリング工業組合連合会を通じて行った 40 社についての調査結果が明らかにされている1)。回答し た企業は資本金が 7000 万円以上 1 億円未満が $76 \%$ を 占め, 回収業之は対照的である。その業務内容は牛脂・ 豚脂・骨油製造が約 7 割を占め, この他に鶏油製造, 廃 油製造, 廃油回収などがあった。後述するようにかなり の廃食用油は, 回収・再生された後配合飼料の添加用油 脂に混合使用されていた。

廃油の入荷を自社だけで行っているのは $11.8 \%$ 之少 なく，回収業者または自社回収も含めて行っているのが
多く，回収業者を自社系列と独立企業に分けると，自社 系列の回収業者と取り引きしているのは 5 社前後と少な かった。

40 社の中, 廃油再生を行っているのは 17 社で, 残り の企業は再生処理をしないか, ごく簡単な処理を行って 販売しているものと思われる。17 社の再生油の販売形 態はいろいろで,「再生油単品とブレンド販売」 7 社, 「再生油単品販売」と「動物油とのブレンド販売」がと もに 4 社あった。

販売先の企業をみると, 脂肪酸分解企業が 8 社, 飼料 製造 12 社, 塗料インク製造 3 社, 燃料利用企業 2 社, その他 5 社となっていた。Table-8に，どのような製 品がどのような販売先に出荷されているかを示した。脂 肪酸分解企業及び飼料製造には「再生油と自社製造動物 油脂とのブレンド」が多く，叙料・インク製造には「再 生植物油単品」が 3 社で用いられており, 回收油の性状 や動植物油の相違によって用途が決まってくる。

業界における問題点としては,「同業者の競争激化」 を挙げるのが 18 社と最も多く，「ユーザーとの価格交 渉」 14 社,「排水処理」「設備の更新」 13 社,「回収業者 との価格交渉」「ユーザーからの品質確保要請」10 社と 続いていた。

以上，業界全体をカバーした調査とはいいがたいが， 廃油再生業の不安定で厳しい状況を示している。

再生油の用途は, 配合飼料向けの添加油脂として約 13 15 万 t, 工業用（脂肪酸分解用，塗料用が主で, せっけん用はごく一部）に約 5 万 $\mathrm{t}$ ，このほかわずかで はあるが燃料に使用されているものと推定される7)。

\section{4 廃食用油の発生・回収・再生の問題点}

\section{$4 \cdot 1$ 廃食用油の発生とその問題点}

業務用として使用されている食用油は家庭で使用され ているものに比べればよく回収・再利用されているとい えるが，それは比較的規模の大きい事業所から定期的に 発生する品質の揃った廃食用油であり, 零細な飲食店や 事業所の廃食用油の大部分は回収されていないと推定さ れる。

Table-7 User of regenerated waste oil.

\begin{tabular}{lccccccc}
\hline \multicolumn{1}{c}{ Number of user } & Total & 1 & 2 & $3-4$ & $5-9$ & 10 & Irrevant case \\
\hline Rendering industry & 44 & 21 & 12 & 4 & 2 & - & 5 \\
Fatty acid manufacturing industry & 44 & 3 & 1 & - & - & 1 & 39 \\
Feed manufacturing industry & 44 & 6 & 5 & - & - & 1 & 32 \\
Food service industry & 44 & - & - & - & - & - & 44 \\
Other & 44 & 3 & - & - & - & 2 & 39 \\
\hline Total company & 44 & 17 & 12 & 10 & 3 & 2 & - \\
& $(100 \%)(38.6 \%)(27.3 \%)(22.7 \%)(6.8 \%)(4.5 \%)$ & \\
\hline
\end{tabular}


Table-8 Variety of regenerated waste oil products and its use.

\begin{tabular}{lcccccc} 
& Total & $\begin{array}{c}\text { Regenerated } \\
\text { vegetable } \\
\text { oil alone }\end{array}$ & $\begin{array}{c}\text { Regenerated } \\
\text { animal } \\
\text { oil alone }\end{array}$ & $\begin{array}{c}\text { Blended } \\
\text { oil* }\end{array}$ & $\begin{array}{c}\text { Unknown } \\
\text { Irrevant } \\
\text { case }\end{array}$ \\
\hline Decomposition of fatty acid & 17 & 3 & 2 & 7 & 1 & 8 \\
Feed manufacturing & 17 & 4 & - & 8 & 1 & 4 \\
Paint \& ink manufacturing & 17 & 3 & 1 & - & 1 & 13 \\
Application to fuel oil & 17 & 2 & 2 & 2 & 1 & 14 \\
Other & 17 & 4 & & - & 10 \\
\hline
\end{tabular}

* Blending of self-produced animal oil with regenerated one. Numbers in Table indicate the number of users of regenerated waste oil.

一方, 家庭から発生する廃食用油は, 藤枝市, 加賀市 などごく一部の自治体が回収事業を実施しているもの の, 2•4 に示したように, 約 8 割がごみとして焼却され ている。家庭で使用中のフライ油の劣化程度は低く ${ }^{5)}$, 外食産業などから発生する廃食用油よりは品質がよいと 思われる。しかしこれが回収されていない原因を考えて みると次のようなことが挙げられる。

(1)一回の発生量, 頻度ともに少ない。

(2)揚げ種が多様で品質にばらつきがある。

(3)中には管理のずさんな家庭もあり, 極端に品質の悪 い, あるいは異物の混入した油が混じる危険性がある。

この中で一番問題になるのは，一家庭・一か月あたり の排出量が $0.5 \mathrm{~L}$ 程度という量の問題であろう。しかし “適当な回収ポイント”を設置して, 現在は回収してい ない零細な飲食店や事業所からの廃食用油も回収できれ ば，再利用への道も開けるのではないだろうか？

家庭で廃食用油をどのように処置したらよいかは議論 のあるところであろう。

「できるだけ少量の油でフライし，フライ後はいため 物に利用して使いきる」との主張があるが, 実際やって みるとかなりの回数の油調理が必要とされる。廃油を出 さないのが理想であるが, 脂肪攝取量の制限が一般的に いわれている現状にはそぐわない。またいため調理時の 油の劣化はフライ調理時よりも激しく8),9), とくに一 度加熱した油の熱酸化は新鮮油を使った場合より早く進 行する。

現在, 半数を超える家庭が 3 回以下の使用回数で廃棄 している。「差し油をしながら上手に使用すれば，十回 以上のフライができる」(10),11) との報告があり，その データの信びょう性に疑いを持たないが，だからといっ て，十回の使用を鹰める気にもなれない。「せめてあと 二回（計 5 回）フライに使用する」あたりが，核家族化 が進む中での現実的な対応策のように思う。

一部に「廃油せっけんの製造」の運動があるが，この 運動の本質は「油を上手に使って廃油を出さない」とこ ろにあるようで，環境污染防止の観点が強い。一般家庭
でせっけんを作ることは危険を伴い，また水質污濁の点 で疑問が残る。

このように考えてくると，油脂資源の有効利用を図 り，焼却による二酸化炭素の排出を抑制するために，家 庭廃食用油を回収・再利用する別の方策を検討する必要 があるのではないだろうか? 著者が家庭廃油のリサイク

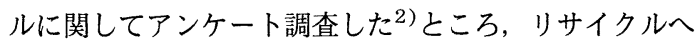
の関心は高く,「地方自治体が家庭廃食用油回収を行っ た場合協力するか？」の問いに対し，86％が「協力し たいと思う」と答え，さらにその費用の一部負担も，60 \%の人が「金額によっては協力する」としている。現 在 $35 \%$ の自治体が収集ごみの有償化に踏み切ってお り, 消費者の多くが市販廃油処理剤を購入使用している のが現状であるから，“有償回収”は理解の得られない ことではなく，具体化に向けた取り組みが必要であろ う。

\section{$4 \cdot 2$ 廃食用油の回収・再生之問題点}

3で紹介した廃油回収業及びレンダリング・廃油再生 業の実態調查は，全国的な調查ではなく不充分なところ もある。とくに再生業についての調査は日本レンダリン グ工業会に属する企業について行われたものであり,こ れ以外の実態については明らかでない。しかし全体的に は，さまざまな問題を抱える業界の実状を浮き彫りにし ていると言えるだろう。

廃食用油の回収は多数の零細企業によって支えられて いるが，近年廃業するものも多く，そこには採算べー ス, 数量及び品質の確保, 後継者の不足など多くの問題 が存在する。リサイクル業界が共通に抱える長期的な景 気停滞による販売価格の低迷, 安価なパーム油の輸入増 加, それに最近の外食産業の落ち込みによるフライ油の 消費減など要因は多い。

回収業が抱える大きな課題は適正な廃油洒格と廃油回 収量の拡大である。近年, 再生業者が回収業者から購入 する価格が低下傾向にあり, “有料回収”を図る以外に 回収業は成り立たなくなってきている。その結果, 回収 費用を支払ってまで回収業者に出すことはせずに，ほか 
$\langle$ Generation〉

$\langle$ Collection $\rangle$

$\langle$ Regeneration〉

$\langle$ Reuse〉

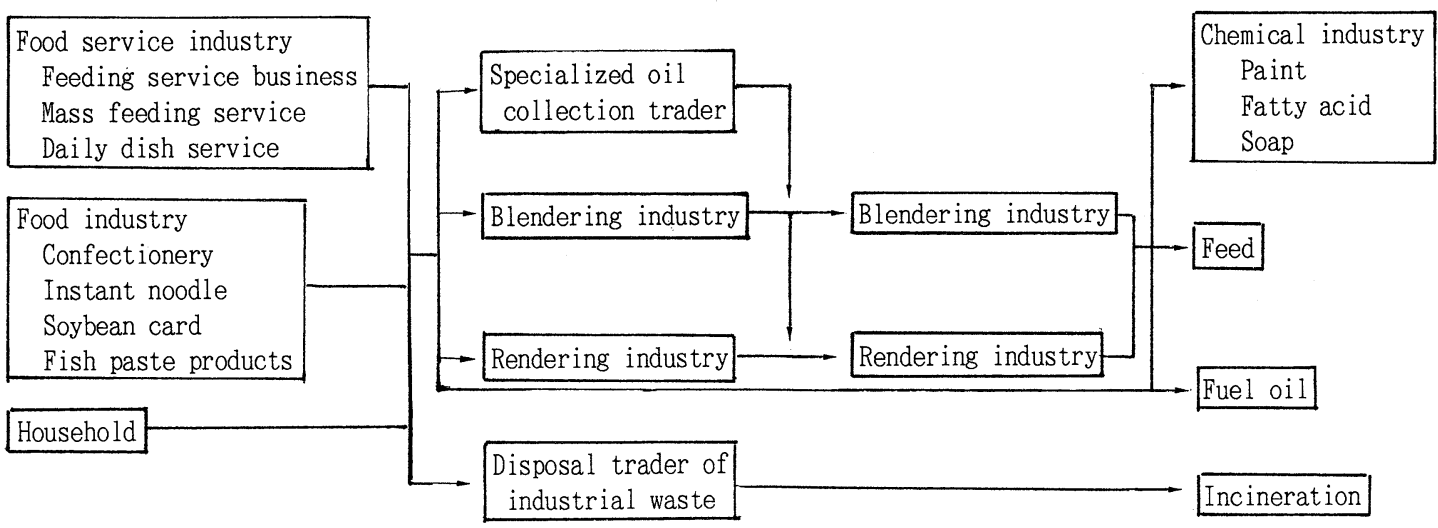

Fig.-1 Flow sheet of used frying oil regeneration for reuse.

の廃棄物と一緒に棄てるのが増えていると言う。

廃食用油は, Fig.-1に示したように, 回収だけを専 門に行っている業者のほか, 動物油脂の製造を行ってい るレンダラーや油脂の精製は行わず再生と調整配合だけ を行っているブレンダラーによって回収されているが, 一部は産業廃棄物処理業者によって廃棄または焼却され ている。先述したように, 小規模な飲食店や事業所など から出る廃食用油のかなりの数量が回収されておらず,

家庭からのそれと併せて, その回収システムの確立が必 要亡される。国では平成 3 年度から「廃食用油リサイク ルモデル推進事業」を開始して, 全国に 5 か所程度のモ デル推進事業市町村を設け, 生ごみのリサイクルと関連 させて, 収集, 輸送, 貯蔵, 再利用についての技術的,

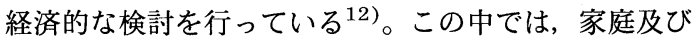
小口事業所の廃食用油は決められたストックポイントに 集められ, タンクローリーによってリサイクルセンター に搬入するように考えられている。このようなシステム が実現するまでにはかなりの課題が残っており，中でも 「収集した廃食用油の新規需要をどのように開拓する か」が大きな問題であり，回収油はたくさん集まったも のの回収・再生業者が経済的に成り立たなくなるようで あってはならない。

再生業は回収業と比較して経営規模が大きく, 再生し た油が飼料添加油としての用途が確保されているだけ, 回収業よりは安定しているといえる。しかし，同業者間 の競争が激しく, 回収油の安定確保, 設備更新, 排水処 理などの難題を抱え，その体質は強いとはいえない。廃 食用油のリサイクルのトータルシステムを構築する中 で，再生業の体質強化についての行財政的検討が当然必 要であろう。

前述のリサイクルモデル事業では, 飼肥料化, せっけ ん化及び燃料化の面からの検討を行っている ${ }^{12)}$ が, こ
の中で，大阪府農林技術センターを中心に行われている ちゅうかい(㕌芥)残飯の油温脱水法 ${ }^{13), 14)}$ は, 生ごみの 有効利用として非常に興味深いが，廃食用油の大半は従 来から飼料製造に使用されているので, 廃食用油の需要 拡大という観点からは大きな期待はできないだろう。

現在稼働している 39 社のせっけん製造企業の中, 再 生油を使用しているのが 28 社あり，この中 12 社は廃食 用油のみ使用していた ${ }^{15)}$ 。廃食用油からのせっけんの 製造についてはかなりの経験が蓄積されており，技術的 には確立されているともいえる。しかし，せっけん生産 の拡大については, 販路の確保, 排水処理への負担の問 題があり，過大な期待はできない。

廃食用油を燃料として利用することは，熱源を必要と する工場などにおいては，発生熱量が重油より約 $10 \%$ 程度劣るものの燃料代の節約にもなり，もっとも手っ取 りばやい廃食用油の処理法といえる。しかし廃食用油は 重油などに比べて引火点, 粘度, 比重がかなり高く, 灰 分も多いために取り扱いが面倒である。重油と混焼する 場合が多いが, 予備加熱をして粘度を下げる, 噴霧バー ナーを使用する，ストレーナーを設置する，専用貯油夕 ンクを新設するなどの工夫が必要である ${ }^{16)}$ という。

十年程前にアメリカを中心に植物油をディーゼル燃料 に使用する研究が行われた ${ }^{17)}$ 結果, 1992 年には Ferruzzi-Montedison 社の子会社 Novamont 社がイ夕 リーに年産 6 万 $\mathrm{t}$ の工場を建設し，ディーゼル代替燃料 としての供給を開始している ${ }^{18)}$ 。現在ディーゼル油に 対して 5〜10\% 添加して使用するのが一般的のようだ が, 硫黄を含まない, 燃焼時の温室ガスの発生量が ディーゼル燃料の $40 \%$ という特徵を有し, 環境問題の 高まりとともに今後普及することが予想される。廃食用 油を用いての基礎研究もいくつか行われているが，実用 化にはまだ若干の時間を要するようだ。いずれにしても 
ディーゼル機関への応用が本格化すれば，廃食用油の再 利用の道は大きく前進するものと思われる。

\section{5 おわりに}

日本における食用油の価格は世界的にみて低く，それ が廃油量を増大させ, 廃油の価値をさらに低くしてい る ${ }^{19)}$ との指摘もあり, 上述したような様々な問題が課 題として横たわるが, 現在廃棄・焼却されている廃食用 油を有効利用する方策は各方面の英知を集めて検討され なければならない。そのための当面の課題として, 次の ようなことが考えられる。

1）回収・再生のトータルシステムを確立する。

現在農林水産省を中心に検討されている「廃食用油リ サイクルモデル事業」を油脂製造メーカー, ユーザー, 回収・再生業者, 自治体の協力のもとに全国的に展開す る。メーカーは回収・再利用まで考慮に入れた商品開発 が要求される。

2）良質の回収油を安定して確保する。

ユーザーには廃食用油の排出方法を徹底させ, 定期的 な回収システムにより，量と質を確保する。

3）回収油の新規用途を開拓する。

生ごみの油温脱水もその一つの方法である。

4) 回収及び再生業界の組織化を進めてその体質を強 化し，適正な競争を図る。

著者が宮城・岩手両県で 1992 年に実施したアンケー 卜調査 ${ }^{20)}$ でも現在の問題として「同業者間の競争」が 第一位に挙げられており, 緊急の課題と考えられる。

廃食用油に対する関心が高まって久しいが, 全体的な 視野から検討されるようになったのは最近のことであ る。本油化学誌にも廃食用油の利用に関する報告 14 ),21) も見られるようになった。著者は, 家庭で使用した揚げ 油を簡単な吸着処理による脱色を図ったが, 脱色性と酸 化安定性の両方を満足させる安価な吸着剂はみつからな かった ${ }^{22)}$ 。廃食用油の処理についての特許報告も見受
けられるが, 廃食用油の再生技術の向上のために, 日本 油化学協会として何らかの取り組みが必要となろう。

〔平成 5 年 (1993 年) 7 月 7 日受理

\section{文献}

1）政策科学研究所,「食用廃油の発生・回収の現状之課 題」, 1989 年 3 月

2) 薄木理一郎, 尚絧女学院短期大学 研 究 報 告, 39, 307 (1992)

3）農林水産省食品流通局食品油脂課，環境庁水質保全局水 質規制課, 厚生省生活衛生局水質環境部環境整備課, 「廃食用油の回収・再利用システム——ガイドライン —」, 1991 年 3 月, p. 44

4) 同上, p. 38

5）薄木理一郎, 尚絧女学院短期大学 研 究 報 告, 33, 115 (1986)

6) 3) に同じ, p. 36

7) 3) に同じ, p. 43

8）福井裕美, 薄木理一郎, 金田尚志, 調理科学, 11,139 (1978)

9) R. Usuki, H. Fukui, M. Kamata, T. Kaneda, Fette, Seifen, Anstrichm., 82, 494 (1980)

10）暮しの手帳, No. 77, (1982) p. 8

11）国民生活センター商品テスト部 :「食用植物油の商品テ ス卜結果」, 1992 年 6 月

12）農林水産省食品流通局食品油脂課, 廃食用油リサイクル モデル事業推進委員会, 廃食用油再利用技術研究会, 「廃食用油リサイクルモデル事業推進検討報告書」, 1992 年 3 月, p. 8

13）同上,「廃食用油リサイクルモデル事業推進検討報告書 (基本設計関連資料)」, 1992 年 3 月, p. 3

14) 吉田善彦, 亀岡俊則, 福島成彦, 油化学, 41, 77 (1992)

15）12) に同じ, p. 24

16）12)に同じ, p. 26

17）村野文男, 油脂, 35 (12), 38 (1982)

18) INFORM, 3, 584 (1992)

19) 安田耕作, 油脂, 44 (5), 62 (1991)

20）薄木理一郎, 未発表

21) 梶本五郎, 山口博司, 油化学, 41, 629 (1992)

22) 薄木理一郎, 調理科学, 26, 7 (1993) 